From Muddling through to the Economics of Control: Views of Applied Policy from J. N. Keynes to Abba Lerner

by

David Colander

October 2005

MIDDLEBURY COLLEGE ECONOMICS DISCUSSION PAPER NO. 05-33

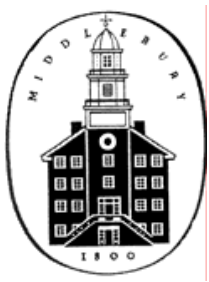

DEPARTMENT OF ECONOMICS

MIDDLEBURY COLLEGE

MIDDLEBURY, VERMONT 05753

http://www.middlebury.edu/ econ 


\section{From Muddling Through \\ to the Economics of Control: \\ Views of Applied Policy \\ from J. N. Keynes to Abba Lerner}

David Colander

This essay tells a story of changing views about economists' conceptions of what economic theory has to say about the role of government in the economy. ${ }^{1}$ It considers three views. One is the view of J. N. Keynes and Lionel Robbins, who argue that pure economic theory has little or nothing to say about policy, but that a separate branch of economics exists that should consider such policy issues. A second view is that of Alfred Marshall and A. C. Pigou, who argue that a "realistic" theory can be used to guide judgments on policy. The third view, which is most closely related to an "economics of control" view set out by Abba Lerner, connects pure theory, policy, and the role of government in the economy in a more direct way, drawing implications about policy and the role of the state from pure theory.

This essay discusses the evolution of these three views and argues that the first two are actually much more compatible than they at first seem. They both can be seen as a "muddling through" approach to policy, in which pure economic theory does not give much guidance for policy. The third view, in which pure theory gives direct guidance for policy, is incompatible with the other two. The essay concludes by arguing that the current textbook presentation of policy follows the third view and that,

I would like to thank D. P. O'Brien and participants of the 2004 HOPE conference, and especially Craufurd Goodwin, for their comments on an earlier version of this essay.

1. This essay is not a full consideration of the issues and does not discuss how outside events influenced economists' thinking. Instead it focuses on economists' changing methodological views about what the role of theory is and of how that theory should be used in thinking about policy. 
while the first two are quite reasonable views, this third view is at best misleading and at worst simply wrong.

\section{J. N. Keynes's Muddling Through}

The standard methodological reference in the late 1800s is J. N. Keynes's Scope and Method of Political Economy ([1891] 1955). In it, Keynes, following earlier economists, divided economics into three branchespositive, normative, and art. He defined the branches as follows: "Positive science ... a body of systematized knowledge concerning what is; normative or regulative science ... a body of systematized knowledge discussing criteria of what ought to be . . ; art . . . a system of rules for the attainment of a given end" (34-35). Keynes's book played an important role in clarifying many of the confusions that had existed in economics and became the standard methodological statement of the time. Keynes argued that maintaining a separate positive science quite distinct from applied policy, which was what he meant by the art of economics, was necessary to avoid confusions about the relation between theory and policy. For Keynes positive theory had no policy implications because of the complexity of those real-world policy problems. Applied policy was necessarily muddling through and should be seen as such.

Keynes was very definite about the highly limited role of theory in applied policy. He writes:

Few practical problems admit of complete solution on economic grounds alone.... when we pass for instance, to problems of taxation, or to problems that concern the relations of the state with trade and industry, or to the general discussion of communistic and socialistic schemes-it is far from being the case that economic considerations hold the field exclusively. Account must also be taken of ethical, social, and political considerations that lie outside the sphere of political economy regarded as a science. (34)

Thus, it would be generally agreed that, in dealing with practical questions, an abstract method of treatment avails less and carries us much less far than when we are dealing with theoretical questions. In other words, in dealing with the former class of questions, we are to a greater extent dependent upon history and inductive generalization. (63) 
We are, accordingly, led to the conclusion ... that a definitive art of political economy, which attempts to lay down absolute rules for the regulation of human conduct, will have vaguely defined limits, and be largely non-economic in character. (83)

The methodology of applied policy for Keynes was quite different from the methodology he saw for positive economics. It was inductive, relying on history and educated common sense. Pure theory-positive economics-was used by Keynes as a backdrop for thinking about policy problems; it was useful to help organize one's thoughts but not to be applied to real-world problems. For Keynes, questions about the role of the state belonged in the art of economics; such questions could only be answered by addressing issues that went far beyond economic theory.

Answers about the role of the state were to be found in a broader philosophical tradition of liberalism. Such policy questions would be decided on economic, moral, practical, political, and social grounds. Economists in their role as individuals or as social philosophers might have something to say about such questions, but as economic theorists they had little to say because in that role they did not consider the noneconomic aspects of the questions. Economics was an input into policy; it did not come to policy conclusions.

In distinguishing between implications that could be drawn from positive theory and implications that could be drawn from the art branch of economics, Keynes distinguished theorems from precepts. A theorem was a conclusion that followed from positive economic theory; it concerned how the economy worked. It did not concern policy questions dealing with the role of the state. A precept was a rule of thumb that concerned policy; it followed from the art of economics and was not derived from economic theory but from introspection, induction, and an educated common sense. Pure theory (positive economics) played a role in developing that educated common sense because it revealed logical errors in initial commonsense reasoning, but otherwise theory was not involved in determining policy or the role of the state. There could be precepts about the role of the state, but there would be no theorems about the role of the state. For Keynes, and for classical economists more generally, the doctrine of laissez-faire was a precept, not a theorem.

The "precept/theorem" and "art/positive/normative" distinctions did not leave much of a role for pure economic theory in guiding economic policy. In terms of the then raging Methodenstreit between those favoring an analytic approach and those favoring a historical approach to 
economics, Keynes's solution gave applied policy to the historicists and gave the scientific branch of economics-positive theory-to the theorists. But his solution also left one with the feeling that the scientists had not won much, since, other than in some unspecified abstract way, positive economics was irrelevant for applied policy.

Keynes's view of theory has a long history in English classical economics and was most directly a continuation of the views of economists such as Nassau Senior ([1836] 1951). In this view theorems are simply logical proofs; they convey nothing other than the implications of assumptions one makes. ${ }^{2}$ Theory was simply a system of logical deductions from a series of postulates derived from introspection, which are not themselves subject to empirical verification. Theory might be useful as a backdrop for pondering the role of the state, but theory would not answer the question of what that role was and would certainly not lend itself to specifying rules of actions that the state should follow.

\section{The Marshallian Straddle}

Methodological pronouncements are seldom followed, and although Keynes's work was generally accepted as the best statement of the state of methodology of the time, few economists carefully followed his methodological prescriptions. ${ }^{3}$ An example is Alfred Marshall, who was a colleague of Keynes. Although clearly Marshall had read and discussed with Keynes the methodological issues that Keynes wrote about, Marshall proceeded to write his Principles of Economics with little direct reference to Keynes's work and did not distinguish between the art and science of economics. Instead, Marshall approached the distinction between theory and policy quite differently, specifically blurring the distinction between positive economics and applied policy, or the art of economics. In fact, in early editions of Principles, he argued against having a separate art of economics and focused on economics as a science. 4

2. The philosopher Alexander Rosenberg (1992) has examined modern micro theory and has argued that it has these characteristics.

3. Economists then, as economists now, do what they do. Actual economics develops with only a weak tie to methodological prescriptions. More often than not, methodology serves as an ex post rationalization for what economists do rather than a guide to what they should do.

4. Marshall argued against the use of the phrase "the art of economics" in the early editions of Principles. However, as Marshall's editor points out, between the third (1895) and fourth (1898) editions, Marshall cut from his Principles a paragraph arguing against using the phrase "art of economics" ([1890] 1961, 2:154). 
He could do this by changing what was meant by the concepts of science and positive economics. Marshall's concept of science was not the logical-deductive science that Keynes had in mind but instead a type of applied science, which was more a type of engineering than it was a pure science. For Marshall, science was about solving real-world problems, not understanding for the sake of understanding. Put another way, for Marshall "science" was a tool in the art of economics. 5

The important point here is that for Marshall, the positive economics of Keynes was practically nonexistent; all economics was art. An economic theorist for Marshall was not a scientist but instead a policy economist who created useful tools that could explicate an actual realworld problem. Marshall simply dismissed the logical-deductive branch of economics as being useless and advocated a type of theory that was, in essence, a sub-branch of art. Marshall justified his position by arguing that economics does not avail itself to long deductive chains of reasoning and thus had to concern itself with shedding light on practical issues. ${ }^{6}$

Unfortunately, Marshall did not make clear precisely what he was doing, and he never discussed how his approach differed from Keynes's. He straddled the methodological issues, as he straddled many issues. ${ }^{7}$ Even with his limited interpretation of theory, Marshall was extremely hesitant to draw policy conclusions. Policy was too complicated and involved too many noneconomic variables. For example, when he discussed the art of economics in the fourth edition of Principles he wrote:

5. Marshall's argument against art and his focus on economics as science must be understood in the context of the times; when he was writing, economics as a separate discipline did not yet exist. The majority of economists he dealt with talked about policy, not theory. Only a small minority did theory or followed a logical-deductive approach. As he was writing Principles, he was also petitioning Cambridge to set up separate tripos in economics and was very much concerned that the objectivity of economics be maintained (Marshall 1902). Given his institutional needs, it is not surprising that he combined the art of economics and positive economics, and called it economics rather than political economy. To have emphasized Keynes's distinction would have worked against his desire to set up a separate tripos in economics.

6. Consistent with that view in Principles, he placed all general equilibrium issues in a twopage footnote (Marshall [1890] 1961, mathematical note 21). Such theoretical issues could not be dealt with using the mathematical techniques available and thus were beyond theorizing.

7. For example, he eschewed mathematics but simultaneously structured his arguments in the Principles so that they could be deduced mathematically. (The mathematics were placed in an appendix if they were included at all.) He incorporated enormous institutional and historical insights into his Principles, but he simultaneously removed the term political from the name of economics discipline, naming his book Principles of Economics rather than Principles of Political Economy. This change in name further moved the profession away from Keynes's methodological perspective because the term political economy suggests that there is an applied branch of economics separate from the theoretical branch, and for Marshall that was not the case. 
Of course an economist retains the liberty, common to all the world, of expressing his opinion that a certain course of action is the right one under given circumstances; and if the difficulties of the problem are chiefly economic, he may speak with a certain authority. But on the whole, though the matter is one on which opinions differ, it seems best that he should do so rather in his private capacity, than as claiming to speak with the authority of economic science. (Marshall [1890] 1898, $2: 154)$

While such careful prescriptions about drawing policy implications from theory may seem to be similar to those of Keynes, there was a major difference between their views. For Marshall, positive theory was a tool of applied policy; it was a working abstraction, a tool, not a truth. ${ }^{8}$ Since theory was only a tool, it was not a problem if one's theoretical apparatus incorporated some normative judgments and institutional realities as long as those value judgments were recognized and were useful in making the theory more applicable. As a tool, theory did not have to be pure; it simply had to be useful.

One can best see Marshall's approach to theory through the tools he devised. Consider the concept of consumer surplus, which Marshall developed as a theoretical tool useful in shedding light on some policy questions. It integrated the welfare of all individuals into an area under a curve and thereby included the implicit value judgment that an individual's welfare was comparable and interchangeable. As a tool of pure science, the models built on that assumption were useless, but as a tool of a practicing economist, the models could be useful in certain instances, as long as in applying the analysis one carefully considered the limiting assumptions on which the analysis was built.

Marshall generally limited the use of his tools to applications for which he thought they fit. For example, consider his view of utility and tastes. He specifically rejects William Stanley Jevons's and Carl Menger's view that economics should be seen as the science of meeting given wants and argues that our wants are not independent. He writes that "while wants are the rulers of life among the lower animals, it is to changes in the forms of efforts and activities that we must turn when in search for the keynotes of the history of mankind" (Marshall [1890]

8. J. M. Keynes (1922, v) summarized Marshall's approach to theory as follows: "The theory of economics is a method rather than a doctrine, an apparatus of the mind, a technique of thinking which helps its possessor to draw correct conclusions." 
1961, 85). He further writes: "The higher study of consumption must come after, and not before, the main body of economic analysis; and, though it may have its beginning within the proper domain of economics, it cannot find its conclusion there, but must extend far beyond" (9091).

For Marshall economic reasoning was an input into a broader policy analysis, and economic theory was an input into economic reasoning that is designed for the policy problem at hand. The difference between Keynes and Marshall is that for Keynes, theory is a deductive set of propositions involving long deductive chains of reasoning from initial assumptions. It is as pure as possible and avoids as many value judgments as possible. Modern general equilibrium theory would be an example of Keynes's pure theory. Theory, for Marshall, was makeshift; it specifically did not involve long deductive chains of arguments, but instead involved short chains of arguments, consistent with his "one thing at a time" approach. Its structure was determined by the policy problem one was addressing, and one would make generally accepted normative assumptions that fit the problem at hand in order to make the theory more useful. For Marshall it was acceptable to integrate value judgments into the theory as long as those value judgments were clearly expressed, and if one took them into account when drawing on theory to arrive at a policy conclusion.

\section{Pigou's Realistic Economics}

A. C. Pigou followed Marshall at Cambridge and set the tone for applied economics that was used in the 1920s and 1930s. While mindful of Keynes's distinction between art and science, Pigou followed Marshall in developing economic theory as a sub-branch of the art of economics rather than as a logical-deductive science. Pigou, however, is much clearer about his method, and he specifically states that he is not doing pure theory but is instead doing what he called "realistic theory." He writes: "Hence it must be the realistic, not the pure, type of science that constitutes the object of our search" (Pigou [1920] 2002, 6). To make this point even clearer, Pigou distinguishes between fruit-bearing theory and light-bearing theory (3). Fruit-bearing theory-realistic theory-is a branch of the art of economics; it is theory designed to solve particular policy problems. Light-bearing theory is pure theory, or theory belonging in Keynes's positive branch of economics. 
As was the case with Marshall, Pigou has nothing to say about pure theory, which was what Keynes meant by positive economics; it simply was not part of Pigou's approach. Pigou's welfare economics must be seen in this light; it was not meant to be a final guide to policy. It was about precepts, not theorems. But, unlike Keynes, whose precepts were largely determined outside economic theory, Pigou's precepts were developed within his realistic theory that embodied generally accepted value judgments.

Since his realistic theory was a tool of the art of economics, the absence of any normative welfare judgments, and the consistency of the analysis among different applications, was far less important than it was for Keynes. As was the case with Marshall, Pigou normally accepted that normative judgments could be built into theory, as long as one was clear about what those judgments were and did not argue that those who disagreed with those value judgments were incorrect based on economic reasoning. Economic theory was a set of tools, not rules, for policymakers.

The approach Pigou took to utility theory was consistent with this policy approach. He specifically did not use the term utility but instead used the term desiredness (23). Desiredness was determinable by introspection and was comparable across averages of individuals. ${ }^{9}$ For Pigou, desiredness was not a precise measure of a consumer's welfare but simply a rough measure for his or her material welfare to be used when thinking about policy issues and in explaining the results of economic analysis to others.

Since the tools were designed to come to a policy conclusion, the embodied value judgments had to be justified. Pigou spends much of his Economics of Welfare doing precisely that. For example, he writes: "It is fair to suppose that most commodities, especially those of wide consumption that are required, as articles of food and clothing are, for direct personal use, will be wanted as a means to satisfaction" (Pigou [1920] 2002, 24). For Pigou, an increase in consumption-meeting people's desires - did not mean that there was definitely an improvement in the welfare of society; he simply meant that it most likely would be an improvement. He devoted many pages of his Economics of Welfare to explaining why, as a general precept, one could use social dividend as a rough guide to welfare for many policy changes.

9. The term utility only shows up once in Pigou's Economics of Welfare, and then only to argue against its use. 
His introspective use of utility led him to include two significant interrelated normative judgments in his analysis. First, he held that, in general, income going to rich people had less positive impact on society's welfare than income going to poor people. Based on this assumption, he could favor policies supporting redistribution from rich to poor if that transfer did not decrease the social dividend. He argued that such transfers "enable more intense wants to be satisfied at the expense of less intense wants" (89). Second, he argued that it was inappropriate to differentiate individuals' abilities to generate pleasure, thus specifically excluding the argument that the rich needed more money to fulfill their more refined tastes. Tastes, he argued, were changeable, and if the poor were given more income, they would develop more refined tastes.

Pigou did not deny that these aspects of his welfare economics involved very specific normative judgments, but, for him, they were reasonable judgments, shared with a large part of the population. They were also necessary judgments to make the tools relevant for applied policy. Since his was realistic theory, not pure theory, Pigou argued that such judgments were quite acceptable as long as one was clear that they were being made.

\section{Lionel Robbins's Political Economy}

Pigou's work on welfare economics provoked a reaction from Lionel Robbins, who, in his famous Essay on the Nature and Significance of Economic Science (1932), specifically criticized the Pigovian-Marshallian approach to theory and policy. His argument is similar to Keynes's argument in 1890 and thus is best seen as a call for the return to the methodology of Keynes's initial art-science distinction. Robbins essentially states that what Pigou and Marshall called theory was not theory at all but was instead something else. For Robbins theory is what Keynes meant by theory-logical abstract deductions - and is what Pigou had classified as "light-seeking theory" to contrast it with the "fruit-seeking theory" that Pigou was interested in.

In making his argument, Robbins resurrected the ordinalist approach to welfare analysis in which economic welfare was not material welfare, as it was for Marshall and Pigou, but, instead, a broader concept that implied satisfaction of desire. The difference between the two definitions had been remarked on by Vilfredo Pareto ([1909] 1971), who made a distinction between utility and ophelimity. Pareto's concept of 
utility was the equivalent of what Pigou called desiredness; it was determinable by introspection and was comparable across averages of individuals. Pareto's concept of ophelimity was the equivalent of Robbins's concept of utility. It referred to satisfaction of desire; it was not determinable or comparable among individuals; it was appropriate for pure science but was of little help in applied policy work. Marshall's and Pigou's economics took the Pareto utility approach; it was a rough-andready guide for policy that embodied generally accepted welfare judgments. Robbins's economics took the ophelimity approach; it concerned precise statements about the welfare of individuals that could be drawn from economic theory.

Robbins criticized the material welfare aspect of Marshall's and Pigou's analysis and chose his definition of economics, "the allocation of scarce resources among alternative ends," to specifically rule out the "study of the causes of material welfare" definition that he attributed to Marshall and Pigou. Robbins argued that any tools involving interpersonal welfare judgments had no scientific basis. Robbins's alternative definition both expanded and contracted the domain of economics. It expanded it because it now included all activities and goods, not just those that affected material welfare. But it simultaneously contracted the domain of economics by limiting the amount of interpersonal comparability that was allowed, since that comparability had no scientific basis. 10

Given his definition of pure theory, Robbins was very careful to say that no policy conclusions followed from economic theory. In his 1981 Ely Lecture, which developed ideas in his book on classical economics (Robbins 1953), Robbins reflected on his argument and expanded on his distinction. There he argued that "the raison d'être of welfare economics" is to be "able to pronounce as a matter of scientific demonstration that such and such a policy was good or bad" (Robbins 1981, 4; emphasis in the original). He stated: "In the great work of Marshall and, still more, Pigou, we are assuming comparisons ... (that are) ... not warranted by anything which is legitimately assumed by scientific economics" (4-5). He cites Bentham as agreeing with him that interpersonal utility comparisons are "in vain" and that any economic analysis based on any assumption about such comparisons is unscientific and therefore outside the domain of economics.

10. For a discussion of the distinction between these two approaches, see Cooter and Rappoport 1984. 
But as was the case with Keynes, Robbins did not stop there; he recognized that his definition of the science of economics was highly limiting and would mean that economics has little, if anything, to say about policy, since "all recommendations of policy involve judgments of value" (6). Thus, he specifically called for a separate branch of economics that he called political economy. He writes: "My suggestion here, as in the Introduction to my Political Economy: Past and Present, is that its use should be revived as now covering that part of our sphere of interest which essentially involves judgments of value. Political Economy, thus conceived, is quite unashamedly concerned with the assumptions of policy and the results flowing from them" $(7,8)$.

Robbins sees political economy as distinct from economics in the stricter sense of the word. It involves "all modes of analysis and explicit or implicit judgments of value." While he does not call it the art of economics, Robbins's political economy is an almost perfect parallel to Keynes's art branch of economics. Moreover, if one sees Pigou's realistic economics as a form of Robbins's political economy, not as pure theory, there is little difference between Robbins's and Pigou's view of how policy analysis needs to be conducted in reference to theory. Pigou was simply developing an approach that Keynes and Robbins said needed to be developed but did not develop and did not believe deserved to be called economic theory.

\section{Abba Lerner's Economics of Control}

The last writer I will consider in this paper is Abba Lerner, whose Economics of Control: Principles of Welfare Economics (1944) provided a template for the approach to policy that current textbooks take. Although Lerner was a student of Lionel Robbins (and Lerner specifically states that the ideas were likely absorbed from his teachers at the London School of Economics, including Robbins and Friedrich Hayek [Lerner 1944, viii]), Lerner's work does not fit nicely into Robbins's methodological position. Instead, it more closely follows Marshall's and Pigou's, since Lerner is drawing policy implications directly from theory. Unfortunately, he did not make clear the distinction between pure and realistic theory that Pigou made. Lerner thus left open the possibility that his policy conclusions followed from pure economic theory, not from a realistic theory that had already embodied numerous welfare judgments that needed to be discussed and accepted before one could apply the results of the analysis. 
The likelihood that people would interpret his work as implying that policy conclusions followed from theory was increased because, unlike Marshall and Pigou who carefully discussed the limitations of theory to drawing policy conclusions, Lerner specifically applied his theories to policy and aggressively related theory to policy conclusions. ${ }^{11} \mathrm{He}$ made no distinction between precepts (derived from the art of economics embodying value judgments in the theory) and theorems (derived from pure theory and quite irrelevant for policy). Thus, he argued that while interpersonal comparisons of welfare were impossible, "probable comparisons" were not and that redistribution policy should be based on "probable total satisfaction" (Lerner 1944, 29). Consistent with this view, he drew out specific rules for how government could achieve the optimal distribution of income.

As opposed to developing tools for policy analysts, who would in turn develop policy precepts, as Marshall and Pigou did, Lerner developed specific rules of policy from pure theory, identifying precisely what government should do to maximize social welfare. These rules, because of their simplicity and clearness, became the template for the textbook presentation of both micro and macro policy discussions. ${ }^{12}$ In microeconomics these rules became the rules of welfare economics involving the equating of marginal social costs with marginal social benefits. These rules, which are known as the Lange-Lerner rules, became the guiding rules of welfare economics. ${ }^{13}$

In macro, Lerner $(1941,4,5)$ developed the rules of functional finance, which involved the government maintaining "a reasonable level of demand at all times" through appropriate fiscal policy and a monetary policy governed only by the need to maintain "the optimal amount

11. In doing so he followed the approach of David Ricardo ([1817] 1953), an approach characterized by Joseph Schumpeter (1954) as the Ricardian vice.

12. Lerner's early writing played an important role in the socialist calculation debate that was ongoing at the time, and Lerner was very much concerned with the arguments behind the state's role in the economy. In that debate Lerner advocated market socialism and argued that socialist planners could give directives to managers to price at marginal costs, thereby achieving maximum social welfare.

13. Specifically, government should adjust resources until the following series of equations are met: $M s b=p=m p r=m p c=v m f=m s c$ (Lerner 1944, 96). His rules on income redistribution did not become part of the textbook template. Lerner agreed that we had no basis for making interpersonal welfare comparisons, but argued that because of the uncertainty principle, redistribution was more likely to improve social welfare than hurt it, and thus he supported redistribution and defined his welfare rules to include redistribution. Later economists switched to a welfare economic focus only on Pareto efficiency. 
of investment" and by the functional needs of the economy, not by any precepts of "sound finance." 14

These policy rules that Lerner developed were not presented as general guidelines to be used in combination with noneconomic considerations, as were the precepts of Marshall and Pigou. Instead, they were presented as firm rules based on economic theory. They were presented as forming the basis of policy-the blueprints that governments should follow-if government wanted to work in the social interest. For example, in the introduction to the Economics of Control Lerner $(1944,6)$ writes: "We shall concentrate on what would be the best thing that the government can do in the social interest-what institutions would most effectively induce the individual members of society, while seeking to accomplish their own ends, to act in the way which is most beneficial for society as a whole. ... Here we shall merely attempt to show what is socially desirable."

In making his arguments, Lerner combined a much longer chain of reasoning into the purely economic analysis than either Marshall or Pigou had been willing to do. ${ }^{15}$ Whereas Marshall's work was primarily partial equilibrium in nature and designed to solve specific policy issues, Lerner drew policy rules from general equilibrium theory, using long chains of reasoning, an approach that Marshall argued against.

Had Lerner followed J. N. Keynes's approach and presented his own work as pure theory, with little relevance for policy, Lerner's economics of control approach would have been consistent with that of previous writers. But Lerner did not take that view. He drew very specific rules about policy from theory, as one might do in a Pigovian-Marshallian framework. In doing so, he ignored the positive/art distinction of Keynes, the economics/political economy distinction of Robbins, and the fruitseeking/light-seeking distinction of Pigou. In short, he moved away from a "muddling through" vision of applied policy, in which pure theory had no direct relevance for policy, a vision held by all previous writers, and

14. Unlike the other economists I have been discussing, Lerner also arrived at definite policy rules for macro policy. He did so because early in his career he became enamored of macroeconomics and became a leading expositor of Keynesian ideas. His exposition of these rules was precise, and they became the foundation for much of the textbook presentation of Keynesian economics.

15. Marshall was not alone in this; during the 1930s and 1940s when Lerner was writing, there was a larger movement occurring in economics from a Marshallian partial equilibrium method to a Walrasian general equilibrium method. Lerner's work was part of this broader movement. 
replaced it with an "economics of control" vision of applied policy, in which specific policy rules followed from pure theory.

\section{Conclusion}

I am primarily a teacher of economics. The reason I am interested in the above history is that it sheds light on how we came to the particular structure of micro and macro that currently dominates the textbooks. That framework remains essentially the framework that Lerner developed, although in macro, with the demise of Keynesian economics, precisely what we are teaching students is unclear.16 The microeconomic framework that we teach is a framework in which we teach students an applied policy approach where policy conclusions seem to be directly drawn from theory. What this history points out is that our current microeconomic textbook presentation would be unacceptable to Keynes, Marshall, Pigou, and Robbins.

Where they differed was not in their view of what policy conclusions could be drawn from theory but rather in where they saw economists fitting into the applied policy process. Keynes's and Robbins's pure theory leads to no applied policy rules; it leads to a framework that might be helpful in thinking about the art of economics, but it does not lead to any policy conclusions. For them, policy discussions belong not in economics but in a separate branch of economics, called either political economy or the art of economics. Marshall's and Pigou's realistic theory leads to applied policy rules, but it does so only because it starts with the premise that all applied policy necessarily involves value judgments, and Marshall and Pigou give explicit consideration to those value judgments and discuss numerous noneconomic issues. Even Lerner's framework, which combines the two approaches, retains an explicit consideration of distributional issues and is built on the assumption that governments have resolved these. Unfortunately, such considerations of the necessary element of value judgments in any discussion of policy are not presented in most economics texts, since they do not distinguish a separate "art of economics" branch for policy or make it clear that they are using tools that already embody normative judgments.

16. Even in macro, the models that many principles textbooks use to discuss monetary and fiscal policy retain significant elements of the ideas of functional finance, although authors are much more circumspect about the policy relevance of the models than were earlier textbook authors. 
All of the economists I have considered, with the possible exception of Lerner, would have a problem with the current textbook microeconomics presentation, because it violates Hume's dictum-that you cannot derive a should from an is. They all accepted the need to go beyond pure economic theory to have anything to say about policy or the role of the state. For all of them, applied policy, and questions about the role of the state in the economy, is a muddle. For them the role of the economic theorist is not to give answers but to provide input into a broader policy decision process that goes far beyond economics. That insight has been lost in the texts, and that is sad.

\section{References}

Cooter, Robert, and Peter Rappoport. 1984. Were the Ordinalists Wrong about Welfare Economics? Journal of Economic Literature 22.2:507-30.

Keynes, J. M. 1922. Introduction to Supply and Demand, by H. D. Henderson. London: Nisbet.

Keynes, J. N. [1891] 1955. The Scope and Method of Political Economy. New York: Kelley and Mellman.

Lerner, Abba. 1941. The Economic Steering Wheel. University Review, June, 2-8.

. 1944. The Economics of Control: Principles of Welfare Economics. New York: Macmillan.

Marshall, Alfred. [1890] 1898. Principles of Economics. 4th ed. London: Macmillan.

- [1890] 1961. Principles of Economics. 9th ed. London: Macmillan. . [1902] 1961. A Plea for the Creation of a Curriculum in Economics and Associated Branches of Political Science. In Marshall [1890] 1961.

Pareto, Vilfredo. [1909] 1971. Manual of Political Economy. Edited by Ann S. Schwier and Alfred N. Page, translated by Ann S. Schwier. New York: Kelley.

Pigou, A. C. [1920] 2002. The Economics of Welfare. Reprint, New Brunswick, N.J.: Transactions Press.

Ricardo, David. [1817] 1953. On the Principles of Political Economy and Taxation. Edited by P. Sraffa and M. Dobb. Cambridge: Cambridge University Press.

Robbins, Lionel. 1932. An Essay on the Nature and Significance of Economic Science. London: Macmillan.

. 1981. Economics and Political Economy. American Economic Review 71 (May): 1-10.

Rosenberg, Alexander. 1992. Economics: Mathematical Politics or Science of Diminishing Returns? Chicago: University of Chicago Press.

Schumpeter, Joseph. 1954. History of Economic Analysis. Edited from manuscript by Elizabeth Boody Schumpeter. Oxford: Oxford University Press.

Senior, Nassau William. [1836] 1951. An Outline of the Science of Political Economy. New York: Kelley. 
Copyright of History of Political Economy is the property of Duke University Press and its content may not be copied or emailed to multiple sites or posted to a listserv without the copyright holder's express written permission. However, users may print, download, or email articles for individual use. 
Copyright of History of Political Economy is the property of Duke University Press and its content may not be copied or emailed to multiple sites or posted to a listserv without the copyright holder's express written permission. However, users may print, download, or email articles for individual use. 